\title{
Yield and Nutrient Uptakes in Wheat under Conservation Agriculture Based Rice-Wheat Cropping System in Punjab, India
}

\author{
Sushil Kumar Kharia ${ }^{1,2} *$, H.S. Thind ${ }^{1}$, Avinash Goyal ${ }^{2}$, Sandeep Sharma ${ }^{1}$ and \\ S. S. Dhaliwal ${ }^{1}$ \\ ${ }^{1}$ Department of Soil Science, Punjab Agricultural University, Ludhiana-141004, India \\ ${ }^{2}$ Division of Agricultural Physics, ICAR-Indian Agricultural Research Institute, \\ New Delhi-110012, India \\ *Corresponding author
}

\section{A B S T R A C T}

\section{Keywords}

Conservation agriculture, Enzyme activities, Rice straw, Rice-wheat system, Tillage.

Article Info

Accepted:

24 January 2017

Available Online:

10 February 2017
Conservation agriculture is a potential solution for increasing yield in wheat crop in the rice wheat cropping system. A study was carried out to assess the impact of the conservation practices in rice-wheat cropping system. The experiment was conducted at the PAU, Ludhiana during 2010-2013. The design of an experiment was split-plot with 12 treatments and 3 replications. The main plot treatments of rice (zero till direct seeded rice, ZT-DSR; conventional till direct seeded rice, CT-DSR; zero till direct transplanted rice, ZT-DTR and puddled transplanted rice, PTR) and sub-plot treatments of wheat (conventional till wheat without rice straw, CTW-R; ZT wheat without rice straw, ZTW-R, and ZT wheat with rice straw retained as surface mulch using Happy Seeder, ZTW+R). The treatment ZTW+R recorded significantly higher grain yield $\left(5.26 \mathrm{t} \mathrm{ha}^{-1}\right)$ than other treatments. The yield attributes viz., 1000 grain weight, spike length, grain weight per spike and grains per spike were significantly higher in ZTW+R than that of ZT/CT with no straw. Significantly higher macronutrients (N, P and K) and micronutrients (Zn, Fe, Mn and $\mathrm{Cu}$ ) uptake were recorded under $\mathrm{ZTW}+\mathrm{R}$ compared with ZT/CT without rice straw. The study recommended that the conservation agriculture practices will gives better soil environment for crop growth and development which may be responsible for enhancement of grain yield and nutrient uptakes.

\section{Introduction}

The rice-wheat cropping system (RWCS) is a dominant cropping system in north-western part of India. This cropping system occupies around 10 Mha areas of Indo-Gangetic Plains of India. The production of RWCS decline or stagnate now a days. The sustainability of RWCS is questionable due to excessive pumping of ground water and repeated pudding for rice establishment. These problems may be generally overcome by resource conserving technologies like direct seeded rice, zero tillage wheat, rice straw as mulch etc. The wheat productivity can be increased by conservation agriculture technologies that are generally responsible for improving soil structure and soil water retention capacity. To avoid the late sowing of wheat, new technologies like Happy Seeder was developed for reduce the rice straw burning problem (Sidhu et al., 2007 and 
2015). Rice grows in an anaerobic condition, while wheat requires an aerobic soil condition. Therefore, the annual conversion of soil from anaerobic condition to aerobic is an important feature for growing wheat crop in the rice-wheat cropping system. So the keeping above facts in view this research work has been done to study the effect of tillage and rice straw management in wheat crop in rice-wheat cropping and its effect on yield and nutrients uptake.

\section{Materials and Methods}

\section{Experimental site and experiment detail}

The field experiment was conducted on rice wheat cropping system at PAU, Ludhiana located at $30^{\circ} 56^{\prime} \mathrm{N}$ and $75^{\circ} 52^{\prime} \mathrm{E}$ during three years (2010-2013). The soil of the experimental farm was a Typic Ustochrept sandy loam soil. The top-soil $(0-15 \mathrm{~cm}$ layer $)$ at the start of experiment was non-saline (electrical conductivity $0.36 \mathrm{dS} \mathrm{m}^{-1}$ ) with $\mathrm{pH}$ 7.88 and contained $4.5 \mathrm{~g} \mathrm{~kg}^{-1}$ Walkley-Black carbon, $8.2 \quad \mathrm{mg} \quad \mathrm{kg}^{-1} \quad 0.5 \mathrm{M} \quad \mathrm{NaHCO}_{3}-$ extractable $\mathrm{P}$ (Olsen et al., 1954) and $50.4 \mathrm{mg}$ $\mathrm{kg}^{-1} 1 \mathrm{~N} \mathrm{NH}_{4} \mathrm{OAc}$-extractable $\mathrm{K}$. The climatic condition of the region was hot- wet summers and cool-dry winters. Annual mean rainfall is $760 \mathrm{~mm}$, about $80 \%$ of which occurs at the kharif season. The long-term average (30 years) mean minimum and maximum temperatures in wheat (November to April) are 6.7 and $22.6^{\circ} \mathrm{C}$ while in rice (June to October) are 18 and $35^{\circ} \mathrm{C}$, respectively.

The design of an experiment was split-plot having 12 treatments with 3 replications. The main plot treatments applied to rice were four combinations of crop establishment methods in rice (zero till direct seeded rice, ZT-DSR; conventional till direct seeded rice, CT-DSR; zero till mechanically transplanted rice, $\mathrm{ZT}$ DTR and puddled transplanted rice, PTR). The three sub-plot treatments in wheat were combinations of tillage and rice straw management options (conventional till wheat without residues, CTW-R; ZT wheat without residues, ZTW-R, and ZT wheat with residues retained as surface mulch using Happy Seeder, ZTW+R). The treatments were assigned to the same experimental plots in the 3 years of the study. The treatment details are summarized in Table 1.

\section{Grain and straw yield of wheat}

Grain and straw yield was recorded from 1.4 $\mathrm{m} \times 9 \mathrm{~m}$ area in the center of each plot. Wheat crop was manually harvested close to ground with a sickle, and all the harvested biomass was removed from the plots. Bundle weights of harvest from a net plot area of $1.4 \mathrm{~m} \mathrm{x} 9 \mathrm{~m}$ were taken after sun drying. Grain yield was recorded after hand threshing. Grain yield is reported on air dry weight basis. Straw yield was determined as difference between bundle weight and grain yield. The details about yield attributing parameters as well as methods for determination macro- and micronutrients are given in Table 2.

\section{Statistical analysis}

All the dataset was analyzed using analysis of variance (ANOVA) and differences among treatments were compared at 5\% level of significance using the IRRISTAT data analysis package (IRRI, 2000). Correlations between the variables were assessed by determining Pearson correlation coefficients (r) and probabilities. In all the analyses, significance was accepted at a level of probability (p) of $<0.05$.

\section{Results and Discussion}

Effect of rice establishment, tillage and rice straw management on yield and yield attributes of wheat

The grain yield of a crop is the net resultant of interaction of various factors and is principle 
criterion for comparing the efficiency of different treatments because ultimate effects of experimental variables are reflected the final yield. Tillage and rice straw management practices in wheat, irrespective of rice establishment systems, significantly affected wheat grain yield grown during third year of experimentation (Table 3). Wheat sown with HS produced significantly 15 and 9 per cent higher grain yield than ZT-R and CT wheat, respectively. Wheat sown with HS was produced significantly 24 and 4 per cent higher straw yield than ZT-R and CT wheat, respectively. Sidhu et al (2007) observed that grain yield of wheat sown with HS was comparable with or higher than $\mathrm{CT}$ wheat sown after straw removal or burning. The grain yield increases with $\mathrm{HS}$ were due to higher spike density and no. of grains per spike. Similarly, Singh et al (2013) also reported that ZT wheat sown with HS produced significantly higher grain and straw yield of wheat as compared to farmer's practice.

Highest harvest index was observed under ZT-R following PTR and lowest was recorded in CT wheat following PTR (Table 3). Rahman et al (2005) reported that 1000 grain weight was significantly higher in $\mathrm{ZT}+\mathrm{R}$ wheat as compared to ZT-R. Spike length under ZT wheat sown with HS and ZT-R was significantly higher as compared to CT wheat (Table 4). Ram et al (2013) found that significantly higher spike length under ZT wheat with rice straw mulch than without mulch. Tillage and rice straw management practices, irrespective of rice establishment systems, significantly affected grain weight spike $^{-1}$ (Table 4).

Table.1 Description of experimental treatments

\section{Rice (main plots)}

$\mathrm{T}_{1}$. Zero till direct seeded rice (ZT-DSR). Residues of previous wheat crop were removed. DSR was sown using same drill as in treatment.

$\mathrm{T}_{2}$. Conventional direct seeded rice (CT-DSR). Residues of previous wheat crop were removed. Tillage for DSR included two passes of harrows and two passes of tyne plough ${ }^{\gamma}$ followed by planking, The DSR was sown using seed cum fertilizer drill in $20 \mathrm{~cm}$ apart.

$\mathrm{T}_{3}$. ZT transplanted rice using mechanical trasplanter (ZT-DTR). Residues of previous wheat crop were removed.

$\mathrm{T}_{4}$. Conventional till puddled transplanted rice (PTR): Residues of preceding wheat crop removed. Puddling (wet tillage) was done twice in $6-8 \mathrm{~cm}$ of standing water using a tractor-mounted puddler followed by planking.

\section{Wheat (sub-plots)}

1. Conventional till wheat after removal of rice residue (CTW-R). Residues of previous rice removed. Tillage operations for CTW included two passes of harrows and two passes of tyne plough followed by planking.

2. Zero till wheat after removal of rice residue (ZTW-R). Wheat was direct seeded in the no till plots using zero till drill.

3. Zero till wheat + residues $(\mathrm{ZTW}+\mathrm{R})$ Residues of previous rice crop retained. Wheat was directly seeded into residues using Turbo Happy Seeder (Sidhu et al., 2015).* 
Table.2 Yield attributing parameters and methods for determination of plant samples for macroand micro-nutrients content in grain and straw

Parameters

Effective tillers and non-effective tiller

Plant height

Spike length

Grains per spike

Grain yield

Straw yield

1000-grain weight

Nitrogen in wheat grain and straw

Phosphorus and potassium in wheat grain and straw
The number of spike and non-spike bearing tillers was counted from middle rows from two spots of one meter row length in each plot at harvest and was expressed as effective and non-effective tillers $\mathrm{m}^{-1}$.

Plant height was recorded from each plot at 10 different selected plants. It was taken from ground level to the tip of the spike. It was expressed as average of 10 plants in $\mathrm{cm}$.

Spike length was recorded from each plot at 10 different plants. It was expressed as average of 10 spikes in $\mathrm{cm}$.

Ten spikes were taken from each plot. Seeds of each spikes were counted and their means taken as grains spike ${ }^{-1}$.

Bundle weights of harvest from a net plot area of $12.6 \mathrm{~m}^{2}$ were taken after sun drying. Grain yield was recorded after hand threshing.

Straw yield was determined as difference between bundle weight and grain yield.

1000 grains were counted from produce of each treatment.

Nitrogen in plant samples was determined by Kjeldahl method

The grain and straw samples were digested using diacid (3 part $\mathrm{HNO}_{3}: 1$ part $\mathrm{HClO}_{4}$ ) according to the procedure detailed by Piper (1966). The phosphorus in the digests was estimated spectrophotometrically by Vanado-Molybdo phosphoric acid method and potassium content was analyzed with the help of flame photometer.

Micronutrient in wheat The grain and straw samples were digested using diacid (3 part grain and straw
$\mathrm{HNO}_{3}: 1$ part $\mathrm{HClO}_{4}$ ) according to the procedure detailed by Piper (1966). 0.5 gram of grain and 1.0 gram of straw samples were taken for digestion. 
Table.3 Effect of rice establishment methods, tillage and rice straw as mulch on grain yield, straw yield and thousand grain weight

\begin{tabular}{|c|c|c|c|}
\hline Treatments & $\begin{array}{l}\text { Grain yield } \\
\left(\mathrm{t} \mathrm{ha}^{-1}\right)\end{array}$ & $\begin{array}{c}\text { Straw yield } \\
\left(\mathrm{t} \mathrm{ha}^{-1}\right)\end{array}$ & $\begin{array}{c}\text { Harvest } \\
\text { index }\end{array}$ \\
\hline \multicolumn{4}{|c|}{ Rice establishment systems } \\
\hline DSR-ZT & 4.84 & 6.23 & 0.44 \\
\hline DSR-CT & 4.84 & 6.21 & 0.44 \\
\hline DTR & 4.88 & 6.37 & 0.43 \\
\hline PTR & 4.77 & 6.48 & 0.43 \\
\hline LSD (0.05) & NS & NS & NS \\
\hline \multicolumn{4}{|c|}{ Tillage and rice straw management practices } \\
\hline CT & 4.77 & 6.68 & 0.42 \\
\hline ZTW-R & 4.47 & 5.32 & 0.46 \\
\hline ZTW+R & 5.26 & 6.97 & 0.43 \\
\hline LSD (0.05) & 0.19 & 0.25 & 0.01 \\
\hline \multicolumn{4}{|l|}{ Interaction } \\
\hline LSD (0.05) & NS & 0.51 & 0.02 \\
\hline
\end{tabular}

Table.4 Effect of rice establishment methods, tillage and rice straw as mulch on yield attributing characters of wheat crop

\begin{tabular}{|c|c|c|c|c|}
\hline Treatments & $\begin{array}{c}\text { Effective } \\
\text { tiller }\end{array}$ & $\begin{array}{c}\text { Non-effective } \\
\text { tiller }\end{array}$ & $\begin{array}{c}\text { Spike length } \\
\text { (cm) }\end{array}$ & $\begin{array}{c}\text { Grain weight } \\
\text { spike }^{-1} \text { (gram) }\end{array}$ \\
\hline Rice establishment systems \\
\hline DSR-ZT & 76.1 & 6.56 & 10.5 & 2.08 \\
\hline DSR-CT & 69.7 & 6.61 & 10.8 & 1.97 \\
\hline DTR & 77.4 & 7.33 & 10.7 & 2.04 \\
\hline PTR & 81.3 & 8.61 & 11.0 & 2.01 \\
\hline LSD (0.05) & NS & NS & NS & NS \\
\hline Tillage and rice straw management practices \\
\hline \multicolumn{6}{|l|l|}{ CT } & 79.8 & 7.67 & 10.5 & 2.01 \\
\hline ZTW-R & 74.9 & 7.54 & 10.9 & 1.90 \\
\hline ZTW+R & 73.7 & 6.63 & 10.8 & 2.16 \\
\hline LSD (0.05) & $\mathrm{NS}$ & $\mathrm{NS}$ & 0.3 & 0.08 \\
\hline Interaction & \multicolumn{5}{|l}{} \\
\hline LSD (0.05) & $\mathrm{NS}$ & $\mathrm{NS}$ & $\mathrm{NS}$ & $\mathrm{NS}$ \\
\hline
\end{tabular}


Table.5 Effect of rice establishment methods, tillage and rice straw as mulch on $\mathrm{N}$ content (\%) and uptakes $\left(\mathrm{kg} \mathrm{ha}^{-1}\right)$ in grain and straw of wheat crop

\begin{tabular}{|c|c|c|c|c|}
\hline Treatments & Grain N content & Straw N content & Total N uptake & N HI \\
\hline Rice establishment systems \\
\hline DSR-ZT & 2.06 & 0.39 & 124 & 0.80 \\
\hline DSR-CT & 2.00 & 0.34 & 118 & 0.82 \\
\hline DTR & 1.94 & 0.35 & 117 & 0.81 \\
\hline PTR & 2.06 & 0.38 & 123 & 0.80 \\
\hline LSD (0.05) & NS & NS & NS & NS \\
\hline Tillage and rice straw management practices & \\
\hline CT & 1.93 & 0.36 & 116 & 0.79 \\
\hline ZTW-R & 2.13 & 0.37 & 115 & 0.83 \\
\hline ZTW+R & 1.99 & 0.37 & 130 & 0.80 \\
\hline LSD $(\mathbf{0 . 0 5})$ & NS & NS & 8.9 & 0.02 \\
\hline Interaction & NS & NS & NS & NS \\
\hline LSD $(\mathbf{0 . 0 5})$ & \multicolumn{5}{|l|}{} \\
\hline
\end{tabular}

Table.6 Effect of rice establishment methods, tillage and rice straw as mulch on $\mathrm{P}$ content (\%) and uptakes ( $\mathrm{kg}$ ha-1) in grain and straw of wheat crop

\begin{tabular}{|c|c|c|c|c|}
\hline Treatments & Grain P content & Straw P content & Total P uptake & P HI \\
\hline Rice establishment systems \\
\hline DSR-ZT & 0.232 & 0.067 & 15.4 & 0.73 \\
\hline DSR-CT & 0.233 & 0.068 & 15.5 & 0.73 \\
\hline DTR & 0.237 & 0.069 & 16.0 & 0.72 \\
\hline PTR & 0.244 & 0.072 & 16.4 & 0.72 \\
\hline LSD (0.05) & NS & NS & NS & NS \\
\hline Tillage and rice straw management practices \\
\hline CT & 0.235 & 0.069 & 15.8 & 0.71 \\
\hline ZTW-R & 0.234 & 0.070 & 14.2 & 0.74 \\
\hline ZTW+R & 0.241 & 0.069 & 17.5 & 0.73 \\
\hline LSD (0.05) & NS & NS & 1.4 & NS \\
\hline Interaction & NS & NS & NS & NS \\
\hline LSD (0.05) & \multicolumn{5}{|l|}{}
\end{tabular}


Table.7 Effect of rice establishment methods, tillage and rice straw as mulch on K content (\%) and uptakes (kg ha-1) in grain and straw of wheat crop

\begin{tabular}{|c|c|c|c|c|}
\hline Treatments & Grain K content & Straw K content & Total K uptake & K HI \\
\hline Rice establishment systems \\
\hline DSR-ZT & 0.416 & 1.00 & 82.4 & 0.25 \\
\hline DSR-CT & 0.393 & 1.00 & 81.3 & 0.24 \\
\hline DTR & 0.410 & 0.963 & 81.4 & 0.25 \\
\hline PTR & 0.408 & 1.07 & 89.5 & 0.22 \\
\hline LSD $(\mathbf{0 . 0 5})$ & NS & NS & NS & NS \\
\hline Tillage and rice straw management practices & 1.01 & 86.6 & 0.23 \\
\hline CT & 0.408 & 1.02 & 72.4 & 0.25 \\
\hline ZTW-R & 0.408 & 1.01 & 91.9 & 0.24 \\
\hline ZTW+R & 0.405 & NS & 7.5 & NS \\
\hline LSD $(\mathbf{0 . 0 5})$ & NS & NS & NS & NS \\
\hline Interaction & NS &
\end{tabular}

Table.8 Effect of rice establishment methods, tillage and rice straw as mulch on Zn content (mg $\mathrm{kg}-1$ ) and uptakes (g ha-1) in grain and straw of wheat crop

\begin{tabular}{|c|c|c|c|c|}
\hline Treatments & Grain $\mathrm{Zn}$ content & Straw Zn content & Total Zn uptake & Zn HI \\
\hline \multicolumn{5}{|c|}{ Rice establishment systems } \\
\hline DSR-ZT & 19.1 & 12.0 & 167 & 0.56 \\
\hline DSR-CT & 19.0 & 10.9 & 159 & 0.58 \\
\hline DTR & 18.4 & 10.1 & 155 & 0.58 \\
\hline PTR & 21.0 & 11.4 & 175 & 0.58 \\
\hline LSD (0.05) & NS & NS & NS & NS \\
\hline \multicolumn{5}{|c|}{ Tillage and rice straw management practices } \\
\hline CT & 19.1 & 11.1 & 165 & 0.56 \\
\hline ZTW-R & 18.9 & 10.9 & 142 & 0.60 \\
\hline ZTW+R & 20.0 & 11.3 & 184 & 0.58 \\
\hline LSD (0.05) & NS & NS & 16 & NS \\
\hline \multicolumn{5}{|l|}{ Interaction } \\
\hline LSD (0.05) & NS & NS & NS & NS \\
\hline
\end{tabular}


Table.9 Effect of rice establishment methods, tillage and rice straw as mulch on Fe content (mg $\mathrm{kg}-1$ ) and uptakes (g ha-1) in grain and straw of wheat crop

\begin{tabular}{|c|c|c|c|c|}
\hline Treatments & Grain Fe Content & Straw Fe content & Total Fe uptake & Fe HI \\
\hline Rice establishment systems & \multicolumn{1}{l|}{} \\
\hline DSR-ZT & 27.3 & 137 & 992 & 0.14 \\
\hline DSR-CT & 31.3 & 133 & 978 & 0.16 \\
\hline DTR & 29.0 & 133 & 992 & 0.14 \\
\hline PTR & 29.7 & 138 & 1040 & 0.14 \\
\hline LSD (0.05) & NS & NS & NS & 0.015 \\
\hline Tillage and rice straw management & 134 & 1039 & 0.14 \\
\hline \multicolumn{7}{|l|}{ CT } & 29.5 & 133 & 835 & 0.15 \\
\hline ZTW-R & 28.3 & 139 & 1127 & 0.14 \\
\hline ZTW+R & 30.2 & NS & 49.0 & NS \\
\hline LSD (0.05) & NS & NS & 98.0 & NS \\
\hline Interaction & NS &
\end{tabular}

Table.10 Effect of rice establishment methods, tillage and rice straw as mulch on Mn content (mg kg-1) and uptakes (g ha-1) in grain and straw of wheat crop

\begin{tabular}{|c|c|c|c|c|}
\hline Treatments & Grain Mn content & Straw Mn content & Total Mn uptake & Mn HI \\
\hline Rice establishment systems \\
\hline DSR-ZT & 17.8 & 20.8 & 217 & 0.408 \\
\hline DSR-CT & 19.6 & 20.4 & 221 & 0.432 \\
\hline DTR & 18.2 & 19.5 & 213 & 0.420 \\
\hline PTR & 18.2 & 21.6 & 227 & 0.390 \\
\hline LSD (0.05) & NS & NS & NS & NS \\
\hline Tillage and rice straw management practices & 19.9 & 218 & 0.395 \\
\hline \multicolumn{6}{|c|}{ CT } & 17.9 & 20.9 & 194 & 0.431 \\
\hline ZTW-R & 18.4 & 20.9 & 247 & 0.412 \\
\hline ZTW+R & 19.1 & NS & 21.2 & NS \\
\hline LSD (0.05) & NS & NS & NS & NS \\
\hline Interaction & NS &
\end{tabular}


Table.11 Effect of rice establishment methods, tillage and rice straw as mulch on $\mathrm{Cu}$ content (mg kg-1) and uptakes (g ha-1) in grain and straw of wheat crop

\begin{tabular}{|c|c|c|c|c|}
\hline Treatments & Grain $\mathrm{Cu}$ content & Straw $\mathrm{Cu}$ content & Total Cu uptake & $\mathrm{Cu} \mathrm{HI}$ \\
\hline \multicolumn{5}{|c|}{ Rice establishment systems } \\
\hline DSR-ZT & 4.37 & 3.19 & 41.0 & 0.52 \\
\hline DSR-CT & 4.26 & 3.06 & 39.4 & 0.52 \\
\hline DTR & 3.96 & 3.02 & 38.6 & 0.50 \\
\hline PTR & 4.74 & 3.46 & 45.0 & 0.50 \\
\hline LSD (0.05) & NS & $\mathrm{NS}$ & 4.06 & NS \\
\hline \multicolumn{5}{|c|}{ Tillage and rice straw management practices } \\
\hline CT & 4.55 & 3.30 & 43.8 & 0.50 \\
\hline ZTW-R & 4.47 & 3.13 & 36.6 & 0.55 \\
\hline ZTW+R & 3.98 & 3.11 & 42.7 & 0.49 \\
\hline LSD (0.05) & $\mathrm{NS}$ & NS & 3.33 & 0.034 \\
\hline \multicolumn{5}{|l|}{ Interaction } \\
\hline LSD (0.05) & NS & NS & NS & NS \\
\hline
\end{tabular}

Macronutrients ( $N, P$ and $K)$ content and uptake

Tillage and rice straw management practices in wheat as well as rice establishment systems failed to cause significant effect on $\mathrm{N}, \mathrm{P}$ and $\mathrm{K}$ content in wheat grain and straw (Table 5). Nitrogen content varied from 1.87 to 2.19 per cent and from 0.32 to 0.41 per cent in wheat grain and straw, respectively. The total $\mathrm{N}$ uptake was significantly higher under ZT wheat sown with HS than ZT-R (12 per cent) and CT (11 per cent).

Phosphorus content varied from 0.222 to 0.255 per cent and from 0.064 to 0.075 per cent in wheat grain and straw, respectively (Table 6). Tillage and rice straw management practices, irrespective of rice establishment systems, significantly affected total $\mathrm{P}$ uptake in wheat. The total P uptake was significantly higher under ZT wheat sown with HS than ZT-R (19 per cent). Even total P uptake was significantly higher (10 per cent) in CT than ZT-R.
Potassium content varied from 0.384 to 0.430 per cent and from 0.91 to 1.13 per cent in wheat grain and straw, respectively (Table 7). The total $\mathrm{K}$ uptake was significantly higher under ZT wheat sown with HS than zero till wheat without rice straw (21 per cent). As tillage and rice straw management in wheat as well as rice establishment systems did not affect macronutrient content in wheat grain and straw therefore, the effect on macronutrient uptake was solely attributed to the variability in wheat grain and straw yields.

Malhi et al., (2007) found that grain and straw $\mathrm{N}$ uptake of wheat significantly higher in ZT with straw retained as surface mulch than ZTChhibba (2010) reported that on an average, $25 \%$ of $\mathrm{N} 25 \% \mathrm{P}$ and $75-80 \%$ of $\mathrm{K}$ retained in cereal crops residues making them valuable nutrient sources.

Zinc content varied from 16.9 to $21.3 \mathrm{mg} \mathrm{kg}^{-1}$ and from 8.97 to $12.5 \mathrm{mg} \mathrm{kg}^{-1}$ in wheat grain and straw, respectively (Table 8). 


\section{Micronutrients content and uptake}

The total Zn uptake was significantly higher under ZT wheat sown with HS than ZT-R (23 per cent) and CT (10 per cent). These results revealed that 36 to 47 per cent $\mathrm{Zn}$ retained in wheat straw.

Iron content varied from 25.5 to $33.2 \mathrm{mg} \mathrm{kg}^{-1}$ and from 129 to $144 \mathrm{mg} \mathrm{kg}^{-1}$ in wheat grain and straw, respectively (Table 9). The total $\mathrm{Fe}$ uptake was significantly higher under ZT wheat sown with HS than ZT-R (26 per cent) and CT (8 per cent).

Manganese content varied from 16.4 to 20.8 $\mathrm{mg} \mathrm{kg}$ and from 18.3 to $23.1 \mathrm{mg} \mathrm{kg}{ }^{-1}$ in wheat grain and straw, respectively (Table 10). The total Mn uptake was significantly higher under ZT wheat sown with HS than ZT-R (21 per cent) and CT (12 per cent). These results revealed that 54 to 64 per cent $\mathrm{Mn}$ retained in wheat straw.

Copper content varied from 3.77 to $5.13 \mathrm{mg}$ $\mathrm{kg}^{-1}$ and from 2.87 to $3.70 \mathrm{mg} \mathrm{kg}^{-1}$ in wheat grain and straw, respectively in different treatments (Table 11). The total $\mathrm{Cu}$ uptake was significantly higher under ZT wheat sown with HS than ZT-R (14 per cent). The results revealed that 42 to 54 per cent $\mathrm{Cu}$ retained in wheat straw.

As tillage and rice straw management as well as rice establishment systems did not affect micronutrients content in wheat grain and straw therefore, the effect on grain, straw and total micronutrients uptake was solely attributed to the variability in wheat grain and straw yields. Chhibba (2010) reported that the nutrient taken up by the cereal crops, on an average, $50-80 \%$ of $\mathrm{Zn}, \mathrm{Mn}$ and $\mathrm{Cu}$ was retained in crop residues making them valuable nutrient sources. Prasad et al., (2010) observed that incorporation of rice and wheat straw significantly increased the $\mathrm{Zn}, \mathrm{Fe}, \mathrm{Mn}$ and $\mathrm{Cu}$ uptakes as compared to straw removal in RWS. The use of organic manures increased uptake of micronutrients which may be attributed to increase in DTPA-extractable micronutrients in soil.

In conclusion our study showed that zero tillage with rice residues as surface mulch $(\mathrm{ZTW}+\mathrm{R})$ improved grain yield of wheat over zero tillage without residue (ZTW-R) after three years of RW cropping sequence. ZTW+R was more effective than ZTW/CTW to enhance the macro and micronutrient uptakes in wheat crop.

\section{Acknowledgement}

The land and infrastructure support of Punjab Agricultural University, Ludhiana for the field study and financial as well technical support of International Maize and Wheat Improvement Center (CIMMYT) through USAID and BMGF funded Cereal System Initative for South Asia (CSISA) project and CGIAR Research Program on wheat (CRP 3.1) are gratefully acknowledged.

\section{References}

Singh, A., Kaur, M., Kang, J.S., Geol, A. 2013. Happy seeder and rotavator technology for in-situ management of paddy straw. Int. J. Adv. Res., 1: 37279.

Chhibba, I.M. 2010. Rice-Wheat Production System: Soil and Water Related Issues and Options. J. Indian Soc. Soil Sci., 58: 53-63.

Malhi, S.S., Lemke, R. 2007. Tillage, crop residue and $\mathrm{N}$ fertilizer effects on crop yield, nutrient uptake, soil quality and nitrous oxide gas emissions in a second 4-yr rotation cycle. Soil and Tillage Res., 96: 269-83.

Piper, C.S. 1966. Soil and plant analysis. Hans Publishers, Bombay. 
Rahman, M.A., Chikushi, J., Saifizzaman, M., Lauren, J.G. 2005. Rice straw mulching and nitrogen response of no-till wheat following rice in Bangladesh. Field Crops Res., 91: 71-81.

Saini, M.K., Phutela, R.P., Walia, U.S. 2013. Effect of straw management techniques and herbicides on microbes in wheat in rice-wheat system. Indian J. Agri. Res., 47(2): 130-136.

Sidhu, H.S., Singh, M., Humphreys, E., Yadvinder-Singh, Bijay-Singh, Dhillon,
S.S., Blackwell, J., Bector, V., Singh, M., Singh, S. 2007. The Happy Seeder enables direct drilling of wheat into rice stubble. Australian J. Experimental Agri., 47: 844-854.

Sidhu, H.S., Singh, M., Yadvinder-Singh, Blackwell, J., Lohan, S.K., Humphreys, E., Jat, M.L., Singh, V., Singh, S. 2015. Development and evaluation of the Turbo Happy Seeder for sowing wheat into heavy rice residues in NW India. Field Crops Res., 184: 201-212.

\section{How to cite this article:}

Sushil Kumar Kharia, H.S. Thind, Avinash Goyal, Sandeep Sharma, S.S. Dhaliwal. 2017. Yield and Nutrient Uptakes in Wheat under Conservation Agriculture Based Rice-Wheat Cropping System in Punjab, India. Int.J.Curr.Microbiol.App.Sci. 6(2): 1698-1708. doi: http://dx.doi.org/10.20546/ijcmas.2017.602.190 